\title{
The Contribution of Advanced Glycation End product (AGE) accumulation to the decline in motor function
}

\author{
Hans Drenth ${ }^{1,2^{*}} \mathbb{D}$, Sytse Zuidema ${ }^{3}$, Steven Bunt ${ }^{1}$, Ivan Bautmans ${ }^{4}$, Cees van der Schans ${ }^{1}$ and Hans Hobbelen ${ }^{1}$
}

\begin{abstract}
Diminishing motor function is commonly observed in the elderly population and is associated with a wide range of adverse health consequences. Advanced Glycation End products (AGE's) may contribute to age-related decline in the function of cells and tissues in normal ageing. Although the negative effect of AGE's on the biomechanical properties of musculoskeletal tissues and the central nervous system have been previously described, the evidence regarding the effect on motor function is fragmented, and a systematic review on this topic is lacking. Therefore, a systematic review was conducted from a total of eight studies describing AGE's related to physical functioning, physical performance, and musculoskeletal outcome which reveals a positive association between high AGE's levels and declined walking abilities, inferior ADL, decreased muscle properties (strength, power and mass) and increased physical frailty. Elevated AGE's levels might be an indication to initiate (early) treatment such as dietary advice, muscle strengthening exercises, and functional training to maintain physical functions. Further longitudinal observational and controlled trial studies are necessary to investigate a causal relationship, and to what extent, high AGE's levels are a contributing risk factor and potential biomarker for a decline in motor function as a component of the ageing process.
\end{abstract}

Keywords: Advanced Glycation End products, Motor function, Ageing, Biomarker, Systematic review

\section{Background}

In the ageing population, decline in motor function such as reduced walking speed, poor balance, and loss of muscle strength are commonly observed phenomena [1-4]. Most human physiologic systems regress with ageing, independently of substantial disease effects, at an average linear loss rate of $0.34-1.28 \%$ per year between the age of 30 and 70 years [5]. The age related loss of skeletal muscle mass, which is accompanied by muscle weakness, is an important contributor to functional decline [6]. More people over the age of 70 are having difficulties performing everyday functions because of motor function related problems [7]. Impaired motor function is a prominent characteristic of physical

\footnotetext{
* Correspondence: j.c.drenth@pl.hanze.nl

${ }^{1}$ Research Group Healthy Ageing, Allied Healthcare and Nursing, Hanze University of Applied Sciences, PO Box 3109, 9701 DC Groningen, The Netherlands

${ }^{2}$ Zuid Oost Zorg, Organisation for Elderly Care. Burg, Wuiteweg 140, 9203 KP

Drachten, The Netherlands

Full list of author information is available at the end of the article
}

frailty and is associated with a wide range of adverse health consequences such as falls, disability, death, hospitalization, and institutionalization [8, 9]. In addition to physical frailty, longitudinal studies suggest that a decreased level of motor function is associated with a decline of cognitive function and a subsequent development of both mild cognitive impairment and Alzheimer's disease [3]. A decline in motor function in older ages could be predicted by biomarkers which could allow for early interventions. Since the early 1980 's, it is proposed that the cross-linking of longlived proteins mediated by Advanced Glycation End products (AGE's) may contribute to the age-related decline of the functioning of cells and tissues in normal ageing. AGE's could, therefore, be a potential biomarker and risk factor for the decline of motor function in the older population [10]. 


\section{Advanced glycation End products and ageing}

The occurrence of AGE's is mediated by non-enzymatic condensation of a reducing sugar with an amino group. AGE's are spontaneously produced in human tissues as an element of normal metabolism which increases with aging [11-14]. The increase of the level of free/unbound and protein bound AGE's in the blood circulation is also determined by an exogenous intake such as food [15]. AGE's are being removed from the body through enzymatic clearance and renal excretion.

It has been proposed that, with ageing, there is an imbalance between the formation and natural clearance of AGE's, leading to the accumulation of AGE's in tissues [16, 17]. In many age related diseases, the accumulation of AGE's is a significant contributing factor in degenerative processes, especially in renal failure, blindness, cardiovascular diseases, and complications of diabetes mellitus [13, 18]. Elevated AGE's levels in patients with diabetes mellitus (DM) is most likely due to an excessive elevation of glucose concentration which consequently accelerates the glycation of proteins $[11,13,18]$. Furthermore, AGE's play a role in neurological disorders such as Alzheimer's Disease (AD) $[13,19]$. Interestingly, Hobbelen et al. [20] ascertained that patients in early stage of dementia and with DM had a significantly higher risk for the development of muscle stiffness/hypertonia (defined as paratonia) compared to those with dementia but without DM (OR =10.7, 95 \% CI:2.2-51.7). In early stage dementia, paratonia already negatively and significantly impacts functional mobility such as walking speed. As the most common cause of dementia, Alzheimer's disease, as well as DM, are related to higher serum concentrations of AGE's, the previous finding in the Hobbelen et al. study prompted the hypothesis that AGE's may partly or indirect be responsible for the development of paratonia. The pathogenesis of paratonia is unclear and central nervous system changes as well as peripheral biomechanical changes are hypothesized [20].

Several types of AGE's have been described and can be categorised into fluorescent cross-linking AGE's, nonfluorescent cross-linking AGE's, and non-crosslinking AGE's. The best chemically characterized AGE's are Pentosidine (fluorescent cross-linking) and Carboximethyl-lysine (CML, non-cross-linking) [21]. Cross-linking AGE's are responsible for an increasing proportion of insoluble extracellular matrix and thickening of tissue as well as increasing mechanical stiffness and loss of elasticity [12, 22, 23]. Cross-linking AGE's are considered as being involved in the pathophysiology of arthritis [24, 25]. In fact, the accumulation of AGE's in human articular cartilage increases cartilage stiffness and brittleness. Consequently, the cartilage becomes increasingly prone to damage and degeneration $[26,27]$. In rheumatoid arthritis, elevated levels of crosslinking AGE's in serum and/or synovial fluids also appear to correlate with the levels of inflammatory markers and the disease activity [24]. Another impact on the musculoskeletal system is within the skeletal bone where AGE-induced crosslinks in the collagen matrix alter the mechanical properties of bone by increasing stiffness and fragility [27-29]. Furthermore, significantly higher AGE's levels were reported in patients with osteoporosis, thereby increasing the risk of fractures $[28,30]$.

Non cross-linking effects are exerted by the binding of AGE's to the receptor for AGE's (RAGE). A wide variety of cells express RAGE, and the interaction with AGE's incites activation of intracellular signalling, gene expression, and production of pro-inflammatory cytokines (such as Interleukin (IL)-6, Tumor Necrosis factor (TNF)-alpha), and free radicals. At the peripheral (tissue) level, these inflammatory processes exhibit powerful proteolytic activity whereby the collagen becomes more vulnerable and tissue elasticity decreases [31, 32]. At the central level (central nervous system), interaction between AGE's, Amyloid-beta and hyperphosphorylated tau-protein induce microglia and astrocytes to upregulate the production of reactive oxygen species, proinflammatory cytokines, and nitric oxide which affects neuronal function [11, 32].

Numerous reviews $[16,33-39]$ on the relation between AGE's and motor function have been published, but the majority of these studies are narrative reviews and therefore showing most often an indirect relationship. The negative effect of accumulating AGE's on the biomechanical properties of peripheral musculoskeletal tissues and the central nervous system (CNS), for example accumulation in specific relevant motor-related brain regions, will plausibly have an impact on motor function. However, evidence regarding this subject is fragmented, and a systematic review on this topic is lacking. Therefore, the aim of this study was to systematically review the literature for the direct relationship between circulating and/or tissue AGE's and motor function.

\section{Methods}

\section{Search strategy}

The Embase, Pubmed, Cinahl, and Web of science databases were searched from the earliest possible date through January 2016. Terms were employed both as free text words and mapped to subject headings terms with explosion when feasible. We utilized all possible relevant terminology regarding AGE's and motor function (decline). For detailed information on search terms, see Table 1 . The search regarding terms for AGE's were combined with our search (with AND) regarding terms for motor function (decline). Search filters were established for studies on humans and the 
Table 1 Detailed search terms

\begin{tabular}{ll}
\hline Entry & Keywords \\
\hline AGE's & "advanced glycosylation end products" (OR) "advanced glycosylation end products receptor (supplementary concept)" (OR) \\
& "advanced glycation end product(s)" (OR) "advanced glycation end product(s) receptor" (OR) "non-enzymatic glycation" (OR)" \\
& non-enzymatic glycosylation" (OR) "glycotoxins". \\
AND & \\
Motor function "musculoskeletal physiological phenomena" (OR) "muscle fatigue" (OR) "muscle strength" (OR) "muscle rigidity" (OR) "muscle tonus" & (OR) "muscle stiffness" (OR) "mechanical stiffness" (OR) "rigidity" (OR) " physical endurance" (OR) "postural balance" (OR) "balance" \\
& (OR) "posture" (OR) "postural control" (OR) "articular range of motion" (OR) "psychomotor performance" (OR) "motor activity" (OR) \\
& "motor skills" (OR) "motor skills disorders" (OR) "coordination" (OR) "motor coordination" (OR) "motor control" (OR) "eye-hand \\
& coordination" (OR) "fine motor" (OR) "fine motor skills" (OR) "neuromuscular manifestations" (OR) "gait" (OR)" gait disorders" (OR) \\
& "walking" (OR) "locomotion" (OR) "falls (accidental)" (OR) "mobility limitation" (OR) "physical mobility" (OR) "physical performance" (OR) \\
& "physical activity" (OR) "activities of daily living" (OR) "motor function" (OR) "motor function decline" (OR) "mobility impairment" (OR) \\
& "functional decline" (OR) "motor inhibition" (OR) "inhibition of action" (OR) "interlimb" (OR) "interlimb coordination".
\end{tabular}

English, Dutch, or German language. Bibliographies from identified articles were reviewed for additional references.

\section{Inclusion criteria and outcome variables}

Studies were included providing that a direct relationship between measured AGE's levels and motor function was described. Motor function was defined as any movement or activity through the use of motor neurons in a broad sense (i.e. motor skills, motor control, coordination, locomotion etc.) and/or physical performance (i.e., activities of daily life (ADL), walking, stair climbing, etc.) and/or musculoskeletal function (i.e., muscle strength or stiffness, range of motion etc.). Studies were excluded when merely the effects of AGE's on tissue level or their relation with specific diseases where described, without any direct outcome on motor function.

\section{Data extraction and study quality}

Data were independently extracted by two reviewers. A standardized data extraction form was exploited to derive the following data from each eligible study: first author, year of publication, study design, study population (age, gender, and co-morbidity); the type of AGE's (e.g., crosslinking, non-crosslinking, and chemical characteristics); and the outcome of motor function and the strength of the relationship between AGE's and motor function (e.g., correlation coefficients, risk ratio's etc.). The methodological quality of each incorporated study was assessed independently by two reviewers. All eligible studies turned out to be observational studies and were assessed with the 12 item EBRO Assessment Tool of Cohort Studies [40]. This tool comprises eight validity questions, one question to decide whether to continue the checklist, two applicability items, and one item for statistical analysis. The two applicability items were disregarded as they merely answer questions to determine if the results are applicable to Dutch healthcare. Therefore, ten criteria remained (Table 2). The included studies were qualified as "good", "moderate", or "low". To qualify as "good", the study should rate "valid and applicable" and include sufficient statistical analyses (e.g., correction for potential confounders). A "moderate" qualification was assigned when the validity items rated "doubtful" and included sufficient statistical analyses or rated only "valid and applicable" for the validity items. Any other scenario would have given the study a "low" methodological qualification (Table 2). In the event of a discrepancy, the final score was decided by consensus.

\section{Statistics}

Risk ratios (RR), Odds ratio's (OR), Hazard ratio's (HR), correlation coefficients, and group differences (mean difference and $95 \%$ confidence interval) were presented as reported in the studies. The subjects' ages were presented as reported in the studies or in means and standard deviations (SD) that were calculated from the available data. If association coefficients were not available, effects sizes (ES) [41] were calculated to estimate the magnitude of the effect of AGE's on specific outcomes when the mean difference and standard deviation of compared groups were available or could be retrieved from confidence intervals.

The following formula were used:

$$
\begin{aligned}
S D= & \sqrt{ }(\text { number of subjects }) \\
& *[\text { upper limit }- \text { lower limit }] /(2 * 1.96) \\
E S= & {[\text { mean } 1-\text { mean } 2] / S D \text { pooled, where } S D \text { pooled } } \\
= & \sqrt{ }\left[\left(S D_{1}^{2}+S D_{2}^{2}\right) / 2\right]
\end{aligned}
$$

Cohen's benchmarks were used to indicate small $(\mathrm{ES}=0.20)$, medium $(\mathrm{ES}=0.50)$, and large $(\mathrm{ES}=0.80)$ effects size [42]. Due to the heterogeneity across the studies, meta-analysis was not performed. 
Table 2 Methodological quality of observation studies with EBRO assessment tool of cohort studies [38]

\begin{tabular}{|c|c|c|c|c|c|c|c|c|}
\hline Item & $\begin{array}{l}\text { Semba et al. } \\
2010[45]\end{array}$ & $\begin{array}{l}\text { Sun et al. } \\
2012[46]\end{array}$ & $\begin{array}{l}\text { Whitson et al. } \\
2014 \text { [47] }\end{array}$ & $\begin{array}{l}\text { Shah et al. } \\
2015[50]\end{array}$ & $\begin{array}{l}\text { Dalal et al. } \\
2009 \text { [43] }\end{array}$ & $\begin{array}{l}\text { De La Maza } \\
\text { et al. } 2008 \text { [49] }\end{array}$ & $\begin{array}{l}\text { Momma et al. } \\
2011[44]\end{array}$ & $\begin{array}{l}\text { Tanaka et al. } \\
2015[48]\end{array}$ \\
\hline $\begin{array}{l}\text { 1. Are the comparing groups clearly } \\
\text { described? }\end{array}$ & Yes & Yes & Yes & Yes & Yes & Yes & Yes & Yes \\
\hline $\begin{array}{l}\text { 2. Can risk of bias sufficiently be } \\
\text { excluded? }\end{array}$ & Yes & Yes & Yes & Yes & Yes & Yes & Yes & No \\
\hline $\begin{array}{l}\text { 3. Is the exposure clearly described } \\
\text { and is the method for assessing } \\
\text { the exposure adequate? }\end{array}$ & Yes & Yes & Yes & Yes & Yes & Yes & Yes & Yes \\
\hline $\begin{array}{l}\text { 4. Is outcome clearly described and } \\
\text { is the method for assessing the } \\
\text { outcome adequate? }\end{array}$ & Yes & Yes & Yes & Yes & Yes & Yes & Yes & Yes \\
\hline $\begin{array}{l}\text { 5. Has exposure outcome been } \\
\text { blinded? }\end{array}$ & Yes & Yes & Yes & Yes & Yes & Yes & Yes & Yes \\
\hline 6. Is there sufficient long follow-up? & $\begin{array}{l}\text { Not } \\
\text { Applicable }\end{array}$ & Yes & Yes & $\begin{array}{l}\text { Not } \\
\text { Applicable }\end{array}$ & $\begin{array}{l}\text { Not } \\
\text { Applicable }\end{array}$ & $\begin{array}{l}\text { Not } \\
\text { Applicable }\end{array}$ & $\begin{array}{l}\text { Not } \\
\text { Applicable }\end{array}$ & $\begin{array}{l}\text { Not } \\
\text { Applicable }\end{array}$ \\
\hline $\begin{array}{l}\text { 7. Can selective loss-to-follow-up } \\
\text { sufficiently be excluded? }\end{array}$ & $\begin{array}{l}\text { Not } \\
\text { Applicable }\end{array}$ & Yes & Yes & $\begin{array}{l}\text { Not } \\
\text { Applicable }\end{array}$ & $\begin{array}{l}\text { Not } \\
\text { Applicable }\end{array}$ & $\begin{array}{l}\text { Not } \\
\text { Applicable }\end{array}$ & $\begin{array}{l}\text { Not } \\
\text { Applicable }\end{array}$ & $\begin{array}{l}\text { Not } \\
\text { Applicable }\end{array}$ \\
\hline $\begin{array}{l}\text { 8. Have important confounders or } \\
\text { prognostic factors been identified } \\
\text { and are they taken into account } \\
\text { in the design or analysis? }\end{array}$ & Yes & Yes & Yes & No & Yes & No & Yes & Yes \\
\hline $\begin{array}{l}\text { 9. Are the study results valid and } \\
\text { applicable? }\end{array}$ & Yes & Yes & Yes & Yes & Yes & Yes & Yes & Yes \\
\hline $\begin{array}{l}\text { 10. Correction for potential } \\
\text { confounders: Odds ratio (OR), } \\
\text { Relative Risk (RR), Absolute Risk } \\
\text { Reduction (ARR), Mean Difference } \\
\text { (MD), Hazard Ratio (HR) }\end{array}$ & Yes & Yes & Yes & No & Yes & No & Yes & Yes \\
\hline Overall quality score & Good & Good & Good & Moderate & Good & Moderate & Good & Good \\
\hline
\end{tabular}

To be eligible for further statistical analysis, the study results should rate "valid and applicable" or "doubtful" on question 9. To qualify "valid and applicable" a longitudinal study had to score "Yes" on the 2 follow up questions (6 and 7) and more than 4 times a "yes" on the remaining validity items ( 1 t/m5 and 8 ). A "doubtful" qualification was given when 4 times a "yes" was scored on the remaining validity items ( $1 \mathrm{t} / \mathrm{m} 5$ and 8 ). When a study scored "yes" less than 4 times on the remaining items, further analysis with the checklist was cancelled. When the study had a cross-sectional design the two questions regarding follow up (6 and 7) were disregarded

\section{Results}

\section{Search results}

The literature search revealed 1154 hits. After eliminating 208 duplicates and after an initial screening of titles and abstracts, 902 studies were excluded. Primary reason for exclusion were that the studies were describing an (indirect) effect only on tissue level $(n=223)$, were disease related $(n=291)$ or in the field of diet and weight $(n=16)$, all without outcome on movement, activity, performance and or function. The remaining excluded studies $(n=372)$ did not meet the inclusion criteria in general. A total of 44 full-text articles were retrieved for further analyses. Examination of the available reference lists of these 44 studies did not reveal additional studies. From the 44 potentially eligible studies, 36 studies were excluded because no relevant outcomes were described $(n=19)$, were narrative reviews $(n=11)$ or were conference abstracts $(n=4)$ and editorial comments $(n=2)$. Finally, eight studies were included for this review. A flowchart of the selection process is presented in Fig. 1.

\section{Study quality}

The study quality of six studies was scored as "good" [43-48]. A moderate score was assigned to two studies $[49,50]$ because potential confounders were not taken into account in the analysis (Table 2).

\section{Data extraction \\ Study design}

Of the eight included studies, six had a cross-sectional design [43-45, 48-50], one had a longitudinal design [46], and one study employed a mixed longitudinal and cross-sectional design [47].

\section{AGE's type}

The chemical characteristics of the reported AGE's was described in six studies [43, 45-49]. Carboxymethyl-Lysine (CML) was quantified in five studies [43, 45-47, 49] and Pentosidine in one study [48]. In two studies the chemical characterisation of the AGE's were not specified, yet measured indirectly by skin fluorescence $[44,50]$. For obtaining 


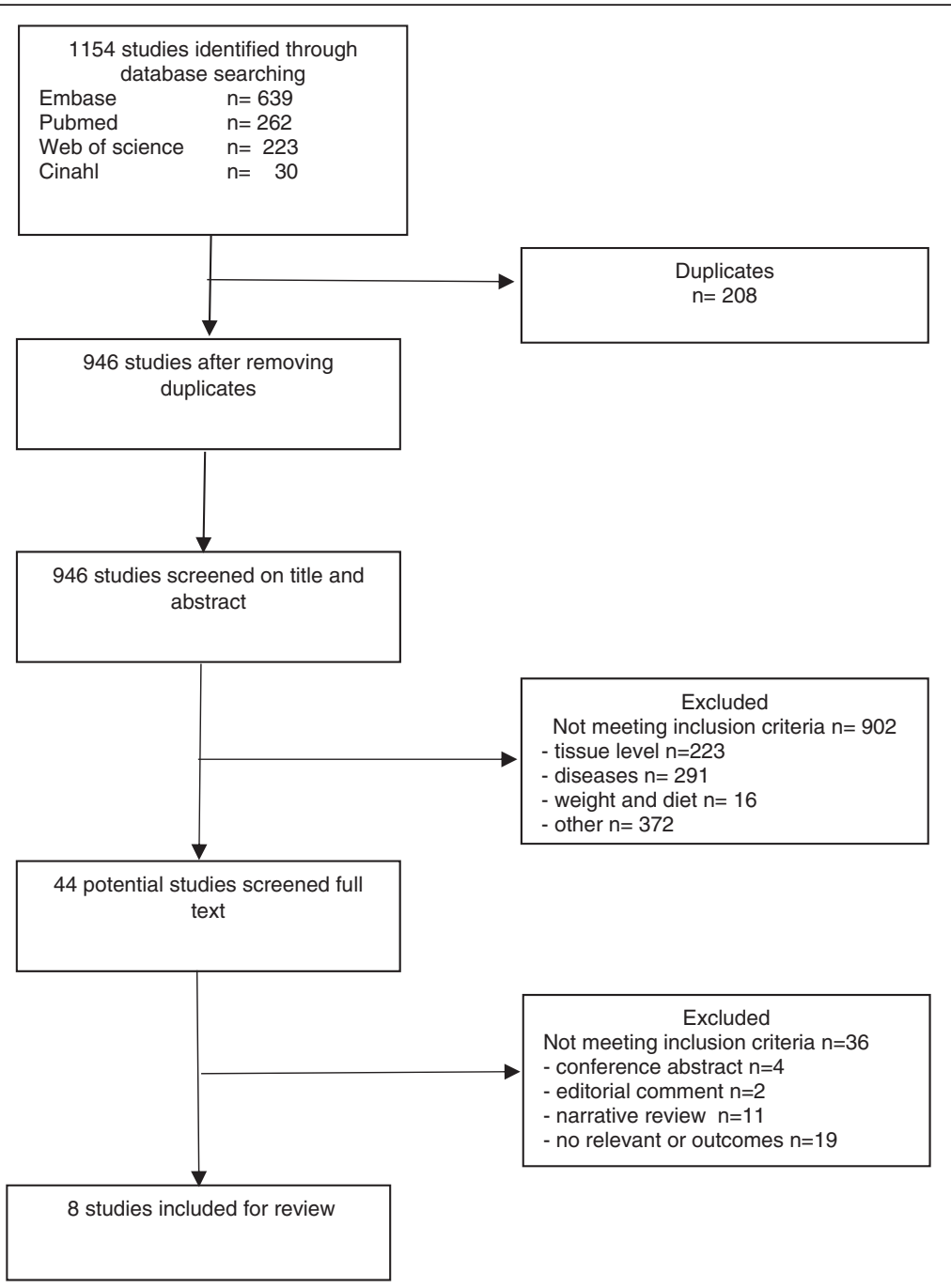

Fig. 1 Flow Chart of selection process

the AGE's levels, blood samples were used in five studies [43, 45-48]; tissue samples in one study [49]; and the noninvasive AGE reader in two studies $[44,50]$.

\section{Motor function outcomes}

The outcomes for motor function from the eight retrieved studies were categorized into three categories;

1) Physical performance and functioning: walking abilities [45, 46], activities of daily living (ADL) [47] and upper extremity function [50];

2) Musculoskeletal: muscle strength, power and mass [43, 44, 48, 49];

3) Physical frailty: in accordance with the Fried criteria [8] and defined as having three or more of the following characteristics: low physical activity, exhaustion, slow walking speed, decreased muscle strength, and unintentional weight loss [47].
Study characteristics and an overview of the main findings and statistics from the studies are provided in Table 3.

\section{Relationship of AGE's with physical performance and functioning Walking abilities}

Walking and the relationship with CarboxymethylLysine (CML) was studied in two studies $[45,46]$. In the cross-sectional study by Semba et al. [45], walking speed was assessed in a representative sample of community dwelling elderly $(n=944)$. Slow walking speed was defined as the slowest quintile of walking speed which was $<0.79 \mathrm{~m} / \mathrm{s}$. Plasma CML was divided into quartiles with the cut-off at the highest quartile established at $424 \mathrm{ng} / \mathrm{mL}$. The study demonstrated that, after adjusting for covariates (age, education, smoking, cognition status, depression, and chronic disease), the subjects in the 
Table 3 Study characteristics

\begin{tabular}{|c|c|c|c|c|c|c|}
\hline $\begin{array}{l}\text { First author/year } \\
\text { of publication }\end{array}$ & Design & $\begin{array}{l}\text { Population } \mathrm{n}=\text {, age, } \\
\text { gender and co-morbidity }\end{array}$ & $\begin{array}{l}\text { AGE/RAGE Circulating/ } \\
\text { Tissue levels, Tissue type }\end{array}$ & $\begin{array}{l}\text { Musculoskeletal } \\
\text { outcome }\end{array}$ & $\begin{array}{l}\text { Physical } \\
\text { performance and } \\
\text { functioning } \\
\text { outcome }\end{array}$ & $\begin{array}{l}\text { Main findings and Outcome } \\
\text { statistics: }\end{array}$ \\
\hline $\begin{array}{l}\text { Semba et al. } \\
2010 \text { [45] }\end{array}$ & Cross-sectional & $\begin{array}{l}\text { Community dwelling } \\
\text { older adults } N=944 \\
(416 \mathrm{M}, 528 \mathrm{~F}) \text {, aged } \\
75 \pm 7 \text { years }\end{array}$ & $\begin{array}{l}\text { Circulating plasma } \\
\text { CML (cut-off value for } \\
\text { high level }=424 \mathrm{ng} / \mathrm{mL} \text { ) }\end{array}$ & - & $\begin{array}{l}\text { Walking speed } \\
\text { (cut-off value for } \\
\text { slow walking } \\
<0.79 \mathrm{~m} / \mathrm{s} \text { ) }\end{array}$ & $\begin{array}{l}\text { Risk for slow walking speed with } \\
\text { high AGE's level: } \\
\mathrm{OR}=1.60(95 \% \mathrm{Cl}: 1.02-2.52)^{* \mathrm{C}} \\
\mathrm{OR}=1.87 \text { (95\% Cl:1.15-3.04)*c } \\
\text { (+ adjusted for DM2) }\end{array}$ \\
\hline $\begin{array}{l}\text { Sun et al. } \\
2012[46]\end{array}$ & $\begin{array}{l}\text { Longitudinal } \\
\text { observational study with } \\
30 \text { month follow-up }\end{array}$ & $\begin{array}{l}\text { Moderately to severe } \\
\text { disabled community } \\
\text { dwelling } F, N=394 \text {, aged } \\
76 \pm 8 \text { years }\end{array}$ & $\begin{array}{l}\text { Circulating serum } \\
\text { CML (cut-off value for } \\
\text { high level = } 689.1 \mathrm{ng} / \mathrm{mL} \text { ) }\end{array}$ & - & $\begin{array}{l}\text { Walking disability } \\
\text { (inability or slow } \\
\text { speed) (cut-off } \\
\text { value for slow } \\
\text { walking }<0.4 \mathrm{~m} / \mathrm{s} \text { ) }\end{array}$ & $\begin{array}{l}\text { Walking disability risk with high } \\
\text { AGE's level: } \\
\mathrm{HR}=1.68(95 \% \mathrm{Cl}: 1.11-2.52)^{*} \\
\mathrm{HR}=1.63(95 \% \mathrm{Cl}: 1.06-2.49)^{* \mathrm{*}}(1) \\
\mathrm{HR}=1.56(95 \% \mathrm{Cl}: 1.04-2.36)^{* c}(2) \\
\mathrm{HR}=1.54(95 \% \mathrm{Cl}: 1.04-2.29)^{* \mathrm{c}}(3) \\
\mathrm{HR}=1.46(95 \% \mathrm{Cl}: 0.95-2.23) \mathrm{NS} .{ }^{\mathrm{C}}(4)\end{array}$ \\
\hline $\begin{array}{l}\text { Whitson et al., } \\
2014 \text { [47] }\end{array}$ & $\begin{array}{l}\text { Longitudinal } \\
\text { observational study with } \\
14 \text { year follow-up for ADL } \\
\text { disability.Cross-sectional } \\
\text { for physical frailty } \\
\text { components }\end{array}$ & $\begin{array}{l}\text { Community dwelling } \\
\text { older adults } N=3373 \\
(1344 \mathrm{M}, 2029 \mathrm{~F}) \text { aged } \\
78.1 \pm 4.8 \text { years }\end{array}$ & $\begin{array}{l}\text { Circulating serum } \\
\text { CML (cut-off value for } \\
\text { high level }=620 \mathrm{ng} / \mathrm{mL} \text { ) }\end{array}$ & \multicolumn{2}{|c|}{$\begin{array}{l}\text { ADL disability } \\
\text { Physical frailty } \geq 3 \text { of following } \\
\text { characteristics: } \\
\text { 1. Low handgrip strength } \\
\text { 2. Unintentional weight loss } \\
\text { 3. Low physical activity } \\
\text { 4. Exhaustion } \\
\text { 5. Slow walking speed }\end{array}$} & 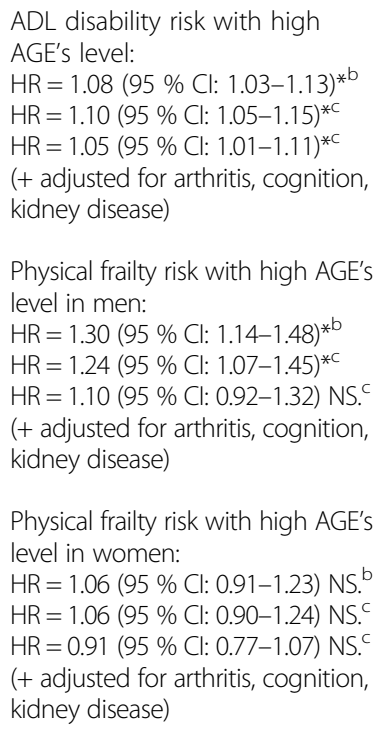 \\
\hline $\begin{array}{l}\text { Shah et al. } \\
2015 \text { [50] }\end{array}$ & Cross-sectional & $\begin{array}{l}\text { DM2 patients } N=26 \\
(13 \mathrm{M}, 13 \mathrm{~F}) \text { aged } \\
64,5 \pm 6,8 \text { Non } \mathrm{DM} N=26 \\
(13 \mathrm{M}, 13 \mathrm{~F}) \text { aged } \\
64,2 \pm 5,8\end{array}$ & $\begin{array}{l}\text { AGE-type not defined } \\
\text { (skin tissue auto } \\
\text { fluorescent Crosslinking } \\
\text { AGE's) }\end{array}$ & $\begin{array}{l}\text { Shoulder flexor } \\
\text { strength }\end{array}$ & $\begin{array}{l}\text { 1. Upper extremity } \\
\text { disability } \\
\text { 2. Upper extremity } \\
\text { function }\end{array}$ & $\begin{array}{l}\text { Correlation flexor strength and } \\
\text { AGE's level: } R=0,07 \text { NS } \\
\text { Correlation Upper extremity } \\
\text { disability and AGE's level: } \\
R=0,51^{*} \\
\text { Correlation Upper extremity } \\
\text { function and AGE's level: } \\
\text { - humerothoracic elevation } \\
R=-0.44^{*} \\
\text { - glenohumeral external } \\
\text { rotation } R=-0.32 \text { NS }\end{array}$ \\
\hline
\end{tabular}


Table 3 Study characteristics (Continued)

\begin{tabular}{|c|c|c|c|c|c|c|}
\hline $\begin{array}{l}\text { Dalal et al. } \\
2009 \text { [43] }\end{array}$ & Cross- sectional & $\begin{array}{l}\text { Moderately to severe } \\
\text { disabled community } \\
\text { dwelling } F, N=559 \\
\text { aged } 76 \pm 8 \text { years }\end{array}$ & $\begin{array}{l}\text { Circulating serum } \\
\text { CML (cut-off value for } \\
\text { high level }=0.68 \mathrm{mg} / \mathrm{mL} \text { ) }\end{array}$ & Handgrip strength & - & $\begin{array}{l}\text { Group difference high vs. low } \\
\text { AGE's level: } \\
18.2(6.4) \mathrm{kg} . \mathrm{vs} .20 .1(6.2) \mathrm{kg} . \\
\text { Beta }-1.88(\mathrm{SE}=0.65)^{*} 18.6 \mathrm{~kg} \\
\text { vs. } 20.0 \mathrm{~kg} \text {, Beta }-1.31 \\
(\mathrm{SE}=0.61)^{* C}\end{array}$ \\
\hline $\begin{array}{l}\text { De La Maza } \\
\text { et al. } 2008 \text { [49] }\end{array}$ & Cross-sectional & $\begin{array}{l}\text { Healthy } M, N=21- \\
\text { Weight maintainers, } \\
N=10,- \text { aged } 41 \pm \\
4 \text { years }- \text { Weight gainers, } \\
N=7 \text {, aged } 42 \pm 5 \text { years } \\
- \text { Elderly, } N=4 \text {, aged } \\
67 \pm 2 \text { years }\end{array}$ & $\begin{array}{l}\text { Skeletal muscle tissue } \\
\text { CML/RAGE }\end{array}$ & Handgrip strength & - & $\begin{array}{l}\text { Correlation grip strength and } \\
\text { AGE's level: } R=-0,54^{*}\end{array}$ \\
\hline $\begin{array}{l}\text { Momma et al. } \\
2011 \text { [44] }\end{array}$ & Cross-sectional & $\begin{array}{l}\text { Healthy } \mathrm{M} \text {, aged } 46 \text { years } \\
(37-56)^{2}-\text { Grip strength } \\
\text { analysis, } N=232-\text { Leg } \\
\text { extension analysis, } \\
N=138\end{array}$ & $\begin{array}{l}\text { AGE-type not defined } \\
\text { (skin tissue auto } \\
\text { fluorescent Crosslinking } \\
\text { AGE's) (cut-off value for } \\
\text { high level = 2.09-4.44 AF) }\end{array}$ & $\begin{array}{l}\text { 1. Handgrip } \\
\text { strength } \\
\text { 2. Leg extension } \\
\text { power }\end{array}$ & - & $\begin{array}{l}\text { Group difference high vs low } \\
\text { AGE's level: } \\
\text { 1. Muscle (handgrip)strength: } \\
41.7 \text { ( } 95 \% \text { Cl: } 40.3-43.1) \mathrm{kg} \text {. } \\
\text { vs.44.5 ( } 95 \% \text { Cl: } 43.2-45.9) \mathrm{kg} . *^{* c} \\
\text { ES }=0.45 \\
\text { 2. Muscle (leg extension) power: } \\
16.0 \text { ( } 95 \% \text { Cl: } 14.9-17.1) \text { W/kg. } \\
\text { vs.17.8 ( } 95 \% \text { Cl: } 16.6-19.1) \\
\text { W/kg.* ES = 0.44 }\end{array}$ \\
\hline $\begin{array}{l}\text { Tanaka et al. } \\
2015[48]\end{array}$ & Cross-sectional & $\begin{array}{l}\text { DM2 patients, } F, N=133 \\
\text { aged } 66,8 \pm 9,5 \text { years }\end{array}$ & $\begin{array}{l}\text { Circulating serum } \\
\text { Pentosidine }\end{array}$ & $\begin{array}{l}\text { 1. Upper extremity } \\
\text { muscle mass } \\
\text { 2. Lower extremity } \\
\text { muscle mass } \\
\text { 3. Relative skeletal } \\
\text { muscle mass } \\
\text { index }\end{array}$ & & $\begin{array}{l}\text { Association UMM and AGE's } \\
\text { level: } R=-0.11 \text { NS Beta }-0.11 \mathrm{NS} \\
\text { Association LMM and AGE's } \\
\text { level: } R=-0.21^{*} \text { Beta }-0.18^{*} \\
\text { Association RSMl and AGE's } \\
\text { level: } R=-0.18^{*} \text { Beta }-0.27^{*}\end{array}$ \\
\hline
\end{tabular}

M Male, F Female, yrs years, AGE Advanced Glycation End product, RAGE Receptor for Advanced Glycation End products, CML Carboxy-methyl-Lysine, DM2 Diabetes Mellitus type 2

a'Median (interquartile range), ES Effect Size, OR Odds Ratio, HR Hazard Risk

bmultivariate adjusted for demographics

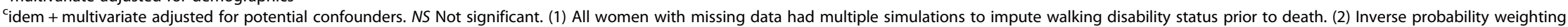
method. (3) All women with missing data treated as developing walking disability prior to death. (4) All women with missing data treated as censored, that is, no walking disability prior to death, UMM Upper extremity

Muscle Mass, LMM Lower extremity Muscle Mass, RSMI Relative Skeletal Muscle Mass Index

${ }^{*} P<0,05$ 
highest quartile of plasma CML were at greater risk of a slow walking speed $(\mathrm{OR}=1.60,95 \% \mathrm{CI}$ : $1.02-$ 2.52, $P=0.04)$ compared to those in the lower three quartiles of plasma CML. After an exclusion of subjects with diabetes and adjusting for the same covariates, the study showed that participants in the highest quartile of plasma CML were at a higher risk for slow walking speed, $(\mathrm{OR}=1.87,95 \% \mathrm{CI} 1.15-3.04, P=0.01)$. In the longitudinal study by Sun et al. [46], walking speed and serum CML were measured in moderately to severely disabled community dwelling female subjects $(n=394)$. Walking disability was defined as the inability to walk or a walking speed of $<0.4 \mathrm{~m} / \mathrm{s}$. Cut-off values according to plasma CML quartiles were 452.6, 558.8 and $689.1 \mathrm{ng} / \mathrm{mL}$. The study showed that subjects in the highest quartile of CML were at a greater risk for developing a walking disability $(\mathrm{HR}=1.68,95 \% \mathrm{CI}: 1.11-2.52, P=0.03)$. Multivariable hazard models for different missing data scenario's (for details, see Table 3) and adjusting for health characteristics (age, congestive heart failure, peripheral artery disease, diabetes mellitus type 2 (DM2), and renal insufficiency) revealed a significantly higher risk for women in the highest quartile of CML to develop a walking disability (HR's between 1.46 and 1.63, all $p<0.05$ ).

\section{Activities of Daily Living (ADL)}

The ability to perform ADL activities and the longitudinal relation with CML in older persons was described in the study by Whitson et al. [47]. Serum CML was measured in participants in the Cardiovascular Health study $(n=3373)$ and was divided into quintiles with the cut-off for the two highest quintiles established at $620 \mathrm{ng} / \mathrm{mL}$. ADL disability was defined as difficulty (yes or no) in any of six ADL activities such as walking around the home, getting out of bed/chair, dressing, bathing, eating, and toileting and was assessed at 6- or 12- month intervals for 14 years. AGE levels were compared between the groups with and without difficulty on the specific ADL activities. After adjusting for potential confounders (demographics, BMI, DM2, alcohol consumption, smoking status, total cholesterol, albumin, weight change, hypertension, heart disease, stroke, and claudication), a high level CML at baseline was associated with $10 \%$ (95 \% CI $5 \%-15 \%$ ) higher incidence of a first ADL difficulty with a hazard ratio (HR) of 1.10 (95\% CI:1.05, 1.15), $p<0,01$ ) per standard deviation (225 ng/mL CML). After further adjusting for arthritis, cognition, and kidney function, an increase in CML was associated with a $5 \%$ (95 \% CI $1 \%-10 \%)$ higher incidence of disability, HR of 1.05 (95\% CI:1.01-1.11, $P=0.03)$ per standard deviation (225 $\mathrm{ng} / \mathrm{mL} \mathrm{CML})$ in both males and females.

\section{Upper extremity function}

Upper extremity function and the relation with AGE's was studied by Shah et al. [50] in groups with diabetes mellitus type 2 (DM2) $(n=26)$ and without DM2 $(n=26)$. Upper extremity disability was measured using the Disability of the Arm, Shoulder and Hand (DASH) self-report questionnaire. The DASH has 30 questions, including disability and pain. The scores were calculated for a range between 0 and $100 \%$, where a higher number indicates more impairments. Skin tissue fluorescent AGE's levels were assessed utilizing an AGE reader. The AGE reader auto-fluorescence (AF) was correlated to the DASH scores $(r=0.51, P=0,009)$ indicating that higher AGE levels correlate with increased disability of arm, shoulder or hand. They also studied the three-dimensional humerothoracic and glenohumeral joint motion and found that AGE reader levels were negatively correlated to humerothoracic elevation $(\mathrm{r}=-0.44, P=0.024)$, but not correlated to glenohumeral external rotation $(\mathrm{r}=-0.32$, $P=0.13)$.

\section{Relationship of AGE's with Musculoskeletal outcome Muscle strength and power}

The contribution of AGE's on the muscle properties strength and power was described in four studies [43, 44, 49, 50]. Dalal et al. [43] examined handgrip strength and circulating CML concentrations in moderately to severely disabled, older females $(n=559)$. The quartile cut-offs for serum CML were $0.45,0.55$, and $0.68 \mathrm{mg} / \mathrm{mL}$. Women in the highest quartile of CML experienced decreased mean grip strength compared with women in the lower three quartiles, $18.6 \mathrm{~kg}$. vs. $20.0 \mathrm{~kg}$, respectively, with a Beta of $-1.88(\mathrm{SE}=0.65, P=0.004)$. After adjusting for covariates (age, race, BMI, cognition, depression, and DM2), a difference was reported of 18.2 (6.4) kg. vs. 20.1 (6.2) kg, respectively, with a Beta of -1.31 (SE $=0.61, P=0.03$ ). The evidence of tissue CML/RAGE in skeletal muscle (internal abdominal oblique) biopsies of healthy subjects $(n=21)$ differing in age and weight stability was studied in the cross-sectional study by de la Maza et al. [49]. The subjects $(n=21)$ were divided into a group of self-reported weight maintainers $(\mathrm{WM})(n=10)$; self-reported weight gainers (WG) $(n=7)$; and elderly (E) $(n=4)$. The study ascertained that handgrip strength was diminished in subjects with an increase of CML/RAGE in muscle tissue and reported a negative correlation $(\mathrm{r}=-0.54, p<0.05)$ between tissue CML and handgrip strength.

The relationship between AGE's and grip strength and leg extension power was described in the study by Momma et al. [44]. In their study, healthy adult males $(n=370)$ were divided into two groups, i.e., one group $(n=232)$ for analysing grip strength and another group 
( $n=138)$ for leg extension strength. Skin tissue fluorescent AGE's levels were assessed utilizing an AGE reader. The tertile cut-off ranges for the AGE reader autofluorescence (AF) were 1.28-1.84, 1.84-2.09 and 2.094.44. After adjusting for potential confounders (age, BMI, physical activity, smoking/drinking status, depression, education, occupation, total energy consumption, metabolic syndrome, DM2, kidney disease, and dietary intake of vitamin C), it was discovered that grip strength was $6.3 \%$ less for those in the highest tertile than for subjects in the lowest tertile of skin $\operatorname{AF}(P=0.01)$. Leg extension power was $10 \%$ lower for those in the highest tertile than for the lowest tertile of $\mathrm{AF}(P=0.04)$.

Shoulder flexor muscle strength and the relation with AGE's was described in the study by Shah et al. [50] in groups with DM2 $(n=26)$ and without DM2 $(n=26)$. Skin tissue fluorescent AGE's were assessed utilizing an AGE reader. The study revealed that AGE reader autofluorescence (AF) was not related to shoulder flexor muscle strength $(\mathrm{r}=0.07, P=0.7)$.

\section{Muscle mass}

Loss of muscle mass and the relation with serum levels of Pentosidine was studied in the study by Tanaka et al. [48] In this study among postmenopausal women with DM2 $(n=133)$ upper and lower extremity muscle mass was measured by Dual-energy $x$-ray absorptiometry and also the relative skeletal muscle mass index $(\mathrm{RSMI}=\mathrm{ap}-$ pendicular skeletal muscle mass $/$ height ${ }^{2}$ ) was calculated. They showed that serum Pentosidine levels were negatively correlated with muscle mass of the lower extremity $(\mathrm{r}=-0.21, P=0.0017)$ and RSMI $(\mathrm{r}=-0.18$, $P=0.039$ ), but not with the muscle mass of the upper extremity $(\mathrm{r}=-0.11, P=0.219)$. After correction for covariates (age, DM2 duration, serum creatinine, glycosylated haemoglobin (HbA1c) and insulin-like growth factor-1 (IGF-1)) they reported that serum Pentosidine levels were associated with RSMI with a Beta of $-0.27 \quad(P=0.008)$ and muscle mass of the lower extremity with a Beta of $-0.18(P=0.071)$.

\section{Relationship of AGE's with physical frailty}

Physical frailty in relation to CML was reported by Whitson et al. [47]. Frailty was based on the five criteria previously described by Fried el al. [8]: less physical activity, self-reported exhaustion, decreased grip strength, slow walking speed, and unintentional weight loss. Participants with three or more criteria were classified as physically frail. In this cross-sectional study serum, CML was measured in older, healthy participants $(n=3373)$. Self-reported exhaustion was identified by evaluation of two statements of the Centre for Epidemiological Studies Depression Scale (CES-D) and was regarded positive if at least one condition was evident for three or more days during the previous week. The decreased physical activity criterion was positive if physical activity per week was $<383 \mathrm{kcal} /$ week for men and $<270 \mathrm{kcal} /$ week for women. Slow walking speed and inadequate grip strength were defined as the lowest $20 \%$ of the population. Finally, unintentional weight loss was defined as unintentional loss of $4.5 \mathrm{~kg}$ in the year prior to the current evaluation or unintentional weight loss of at least $5 \%$ of the previous year's body weight.(7) AGE levels were compared between groups with or without presence of the specific frailty components. Mean CML levels were significantly higher in men for low physical activity $(p=0.007)$, exhaustion $(p<0.001)$ and decreased grip strength $(p=0.04)$, resulting in a significant association with the physical frailty phenotype $(\mathrm{OR}=1.30,95 \% \mathrm{CI}: 1.14-1.48, p<0.001)$. After adjusting for potential confounders (demographics, BMI, DM2, alcohol consumption, smoking status, total cholesterol, albumin, weight change, hypertension, heart disease, stroke, and claudication), a significant association remained (OR $=1.24,95 \% \mathrm{CI}: 1.07-1.45, p=0,04)$. The associations lost significance after further adjustment for arthritis, cognition, and kidney function. No significant associations between CML and low physical activity, exhaustion, and grip strength were determined for females. Furthermore, in men and women with a slow walking speed and unintentional weight loss, CML levels were higher, however, these differences in CML levels were not significant.

\section{Discussion}

The results of this systematic review indicate that higher levels of AGE's are independently related to declined walking abilities, inferior ADL, decreased muscle properties (strength, power, mass) and increased physical frailty.

The available literature on musculoskeletal outcomes $[43,44,48,49]$ support the hypothesis that high AGE's levels are associated with a decline in muscle function. However, the correlations, Beta coefficients and calculated effect sizes indicate only a moderate relationship. It is known that AGE's can affect muscle function through a variety of pathways. In fact, AGE's can alter the biomechanical properties of muscle tissue, increasing stiffness and reducing elasticity through cross-linking and upregulated inflammation by RAGE binding and endothelial dysfunction in the intra-muscular microcirculation [43-46, 49, 51]. This is also consistent with studies on sarcopenia in which decreased muscle mass and strength is explained by an overall increase in inflammatory burden [6]. Examining the studies in this review that report decline in walking abilities, it is suggested by the authors that this decline is also attributed to the effects of AGE's on muscle tissue, thereby 
impairing muscle function $[45,46]$. It has been considered that impaired muscle function - through AGE's-induced muscle damage - can contribute to decline in walking abilities and ADL and can also contribute to physical frailty.

It remains ambiguous to what extend ADL involving the upper extremity are affected by high AGE's level. One small study [50] reports a relation with upper extremity disability, but further we could not identify which ADL are affected most by AGE's and if at all are related to upper extremity function. Thereby in a large study [47] the reported increased risk in inferior ADL is described as the association between baseline AGE's level and the time to first difficulty on any of the six self-reported ADL items and, although significant, the risk is low $(\mathrm{HR}=1.10)$, therefore the practical importance is unclear.

Furthermore our review shows that the decline of handgrip strength is positively associated with higher AGE levels in three studies [43, 44, 49]. Interestingly, in the upper extremity shoulder muscles no association with high AGE levels is found in two studies [48, 50]. The underlying mechanism for this difference in the upper extremity remains unclear and further research is necessary on this topic.

We identified only 8 studies due to strict inclusion criteria for several reasons; 1) We restricted the inclusion to individual studies that reports a direct relationship between AGE's and functioning which enabled us to calculate effect sizes, association coefficients etc. for direct comparison of the strength of the association. 2) To increase internal validity we were specifically interested in motor functioning so we excluded papers measuring solely an effect on tissue levels. 3) Also we did not include papers that only cover a specific disease (such as Diabetes) to increase external validity. As mentioned previously, AGE's have an effect on different types of human tissues [24, 26, 31, 32]. It must be considered that other AGE's-induced effects, such as effects on the nervous system, ligaments, tendons or joint capsules, could contribute to the decline of physical performance and functions. Future research should, therefore, explore other possible underlying AGE's related pathways, not only on the pathophysiological changes on the tissue level, but also with a direct relation on motor function.

The current systematic review shows that the relation between AGE's and motor function is not as strong as most narrative reviews suggest. Although the quality of the included studies was good to moderate, they employed a cross-sectional or observational design, therefore, a causal relationship cannot be inferred. A meta-analysis was not appropriate because of the heterogeneity of the studies.
It is known that, in addition to cognitive decline, accompanying decline in motor function is frequently reported in patients with dementia [52] and it is suggested that AGE's formation may explain many biochemical and neuropathological changes in the most common cause of dementia [13]. However, the results from this review provide no conclusive evidence for a peripheral or a central level effect of AGE's on motor function in Alzheimer's disease or other types of dementia. We were unable to locate any study describing the effect of AGE's on the CNS with a direct relation on motor function. It remains unclear if AGE's accumulate in specific relevant motor-related brain regions, having their effect on the complex inter-relationship between the distributed motor networks within the CNS as well as with the musculoskeletal structures for generating movement. Future research is required to determine the contribution of AGE's accumulation on the CNS with a direct relation on the decline in motor function.

It is important to realise that, in this review, decline in motor function was primarily associated with elevated CML levels. Association with circulating CML was determined in four studies [43, 45-47], and a relation with tissue CML was found in one study [49]. One study reported an association with Pentosidine [48] and two other studies with non-specified skin tissue fluorescent AGE's $[44,50]$. It is suggested that fluorescent and nonfluorescent AGE's such as CML behave similarly and fluorescence may be employed as a marker for the total skin tissue AGE's pool [53]. Although CML is a dominant AGE in blood circulation and correlates with other AGE's [14], it is possible that the association between AGE's and motor function outcome could be different if crosslinking AGE's such as Pentosidine were assessed.

In five studies, only females $[43,46,48]$ or males $[44,49]$ were included, therefore, the reported decline in motor function with elevated AGE's cannot necessarily be extrapolated to the other gender. Previous longitudinal studies conducted in a large cohort suggest that the relation between serum AGE's and health elevated levels of serum AGE's were associated with all-cause mortality, cardiovascular disease, and coronary heart disease mortality only in women $[54,55]$. In contradiction, Whitson et al. [47] found a significant cross-sectional association between CML and physical activity, exhaustion, and muscle strength as components of physical frailty only among men and not among women. A possible explanation suggested by Whitson et al. is that aged cohorts may be subject to gender-specific survivor bias. They state that the relative significance of CML mediated factors in determining the risk of death is greatest for females prior to menopause but greater for men in advanced ages. If AGE's have more effect on women, higher-risk women may then be unlikely to participate in studies that measure CML late 
in life due to the negative health outcomes [47]. On the other hand, they did find an association with men and women in their longitudinal study on ADL disability. In a comparable cohort, Semba et al. [45] reported a strong association between men and women and do not report any significant gender differences. Therefore, this raises an additional question of whether or not the effect of AGE's could be gender specific. Future research should, therefore, include gender-based differences in the effects of AGE's.

The vast majority of participants included in this review were elderly people older than 64 years $(n=5433)$. Interestingly, in two studies [44, 49], the participants were middle-aged between 37 and 56 years $(n=387)$. This indicates that the negative effect of AGE's on motor function already begins during midlife and, as AGE's levels increase with ageing, could be an important factor in age related decline in motor function. A high AGE's level, as a biomarker, therefore, could predict a decline in motor function later in life. This could also imply that preventive interventions should start as soon as possible as part of healthy ageing. In accordance with the results of this review, it would be interesting to investigate whether motor function can be improved by reducing AGE's levels. Intensive glycaemic control may be a method to decrease AGE's formation. CML levels correlate to dietary consumption [14], therefore, dietary intake is a possible factor that can be influenced. It is suggested that, in order to lower daily AGE's intake, foods rich in sugar and fat and those prepared by frying or grilling should be avoided $[14,56]$. However, evidence of the harmful effects of long-term exposure to dietary AGE's is still inconclusive [15]. Improvements of glycaemic control by regular physical exercise could also attenuate the formation and accumulation of AGE's [11, 21, 57]. Elevated AGE's levels might be an indication to initiate (early) treatment such as dietary advice, muscle strengthening exercises, and functional training to maintain physical functions. However, literature regarding the effects of physical exercise on AGE's formation is minimal, and the optimal exercise modalities remain ambiguous [21]. Further research should focus on whether dietary modifications, exercise programs, or medication to reduce AGE's levels can prevent or counter decline in motor function.

\section{Conclusion}

This review indicates that decline in motor function is independently associated with high AGE's levels. Further longitudinal observational and controlled trial studies are necessary to investigate a causal relationship, and to what extent, high AGE's levels are a contributing risk factor and potential biomarker for decline in motor function as a component of the ageing process.

\section{Abbreviations}

AD: Alzheimer's disease; ADL: activities of daily life; AF: auto-fluorescence; AGE'S: Advanced Glycation End products; BMI: body mass index; CESD: Centre for Epidemiological Studies Depression Scale; CML: carboximethyllysine; CNS: central nervous system; DASH: disability of the arm shoulder and hand; DM: diabetes mellitus; DM2: diabetes mellitus type 2; EF: effects size; HbA1c: glycosylated haemoglobin; HR: hazard ratio; IGF-1: insulin-like growth factor-1; IL-6: interleukin-6; OR: odds ratio; RAGE: receptor for advanced glycation end products; RR: risk ratio; RSMl: relative skeletal muscle mass index; SD: standard deviation; TNF: tumor necrosis factor; WG: weight gainers; WM: weight maintainers.

\section{Competing interests}

The authors declare that they have no competing interests.

\section{Authors' contributions}

$\mathrm{HD}$ is the first author and was responsible for the conception and design, the acquisition of data, the interpretation of data, and drafting the manuscript. SZ has been involved in the conception and design and has been involved in reviewing the manuscript critically for important intellectual content. SB has been involved in the quality assessment of the included studies, in the data extraction and reviewing the manuscript critically for important intellectual content. IB has been involved in reviewing and revising the manuscript critically for important intellectual content. CS has been involved in revising the manuscript critically for important intellectual content. $\mathrm{HH}$ has been involved in the conception and design, reviewing the manuscript critically for important intellectual content, and has given final approval of the version to be published. All authors read and approved the final manuscript.

\section{Acknowledgements}

This work was supported by regular funds of the Research Group Healthy Ageing, Allied Healthcare and Nursing, Hanze University Groningen, the Department of General Practice, University Medical Center Groningen, the Frailty in Ageing Research Group and Gerontology Department, Free University of Brussels and ZuidOostZorg, Organisation for Elderly Care, Drachten.

\section{Author details}

${ }^{1}$ Research Group Healthy Ageing, Allied Healthcare and Nursing, Hanze University of Applied Sciences, PO Box 3109, 9701 DC Groningen, The Netherlands. ${ }^{2}$ Zuid Oost Zorg, Organisation for Elderly Care. Burg, Wuiteweg 140, 9203 KP Drachten, The Netherlands. '3 Department of General Practice, University of Groningen, University Medical Center Groningen, PO Box 196 9700 AD, Groningen HPC FA21, The Netherlands. ${ }^{4}$ Frailty in Ageing Research Group and Gerontology Department, Free University of Brussels,

Laarbeeklaan 103, B-1090 Brussels, Belgium.

Received: 17 September 2015 Accepted: 1 March 2016

Published online: 04 March 2016

\section{References}

1. Arvanitakis Z, Wilson RS, Schneider JA, Bienias JL, Evans DA, Bennett DA. Diabetes mellitus and progression of rigidity and gait disturbance in older persons. Neurology. 2004;63:996-1001.

2. Bellew JW, Symons TB, Vandervoort AA. Geriatric fitness: effects of aging and recommendations for exercise in older adults. Cardiopulm. Phys Ther J. 2005;16:20-31.

3. Buchman AS, Bennett DA. Loss of motor function in preclinical Alzheimer's disease. Expert Rev Neurother. 2011;11:665-76.

4. Rikkert MGO, Rigaud AS, van Hoeyweghen RJ, de Graaf J. Geriatric syndromes: medical misnomer or progress in geriatrics? Neth J Med. 2003;61:83-7.

5. Sehl ME, Yates FE. Kinetics of human aging: I. Rates of senescence between ages 30 and 70 years in healthy people. J Gerontol A Biol Sci Med Sci United States. 2001;56:B198-208.

6. Bautmans I, Van Puyvelde K, Mets T. Sarcopenia and functional decline: pathophysiology, prevention and therapy. Acta Clin Belg. 2009;64:303-16.

7. U.S. Department of Health and Human Services. Healthy People 2000 Review. 1999. 
8. Fried LP, Tangen CM, Walston J, Newman AB, Hirsch C, Gottdiener J, et al. Frailty in older adults: evidence for a phenotype. Journals Gerontol A, Biol Sci Med Sci. 2001;56:M146-56.

9. Sternberg SA, Schwartz AW, Karunananthan S, Bergman H, Clarfield AM. The identification of frailty: a systematic literature review. J Am Geriatr Soc. 2011:59:2129-38.

10. Sprott RL. Biomarkers of aging and disease: introduction and definitions. Exp Gerontol. 2010;45:2-4.

11. Ahmed N, Thornalley PJ. Advanced glycation endproducts: what is their relevance to diabetic complications? Diabetes, Obes Metab. 2007;9:233-45

12. Monnier VM, Mustata GT, Biemel KL, Reihl O, Lederer MO, Zhenyu D, et al. Cross-linking of the extracellular matrix by the maillard reaction in aging and diabetes: an update on "a puzzle nearing resolution.". Ann N Y Acad Sci. 2005;1043:533-44.

13. Rahmadi A, Steiner N, Munch G. Advanced glycation endproducts as gerontotoxins and biomarkers for carbonyl-based degenerative processes in Alzheimer's disease. Clin Chem Lab Med. 2011:49:385-91.

14. Uribarri J, Cai W, Peppa M, Goodman S, Ferrucci L, Striker G, et al. Circulating glycotoxins and dietary advanced glycation endproducts: two links to inflammatory response, oxidative stress, and aging. Journals Gerontol A, Biol Sci Med Sci. 2007:62:427-33.

15. Van Puyvelde K, Mets T, Njemini R, Beyer I, Bautmans I. Effect of advanced glycation end product intake on inflammation and aging: a systematic review. Nutr Rev. 2014;72:638-50.

16. Luevano-Contreras C, Chapman-Novakofski K. Dietary advanced glycation end products and aging. Nutrients. C. Luevano-Contreras, Division of Nutritional Sciences, University of Illinois at Urbana-Champaign, Urbana, IL 61801, United States; 2010;2:1247-65.

17. Peppa M, Uribarri J, Vlassara H. Aging and glycoxidant stress. Hormones (Athens). 2008:7:123-32.

18. Gasser A, Forbes JM. Advanced glycation: implications in tissue damage and disease. Protein Pept Lett. 2008;15:385-91.

19. Munch G, Westcott B, Menini T, Gugliucci A. Advanced glycation endproducts and their pathogenic roles in neurological disorders. Amino Acids. 2012;42:1221-36

20. Hobbelen JS, Tan FE, Verhey FR, Koopmans RT, de Bie RA. Prevalence, incidence and risk factors of paratonia in patients with dementia: a one-year follow-up study. Int Psychogeriatr. 2011:23:1051-60.

21. Magelhaes PMJ, Appell H, Duarte JA. Involvement of advanced glycation end products in the pathogenesis of diabetic complications: the protective role of regular physical activity. Eur Rev Aging Phys Act. 2008;17.

22. Kjaer M. Role of extracellular matrix in adaptation of tendon and skeletal muscle to mechanical loading. Physiol Rev. 2004;84:649-98.

23. Avery NC, Bailey AJ. Enzymic and non-enzymic cross-linking mechanisms in relation to turnover of collagen: relevance to aging and exercise. Scand J Med Sci Sports. 2005;15:231-40.

24. Takahashi M. Pentosidine, an advanced glycation endproduct, and arthritis. Curr Rheumatol Rev. 2006;2:319-24

25. Verzijl N, DeGroot J, Ben ZC, Brau-Benjamin O, Maroudas A, Bank RA, et al. Crosslinking by advanced glycation end products increases the stiffness of the collagen network in human articular cartilage: a possible mechanism through which age is a risk factor for osteoarthritis. Arthritis Rheum. 2002;46:114-23.

26. Verzij N, Bank RA, TeKoppele JM, DeGroot J. AGEing and osteoarthritis: a different perspective. Curr Opin Rheumatol. 2003;15:616-22.

27. Karim L, Tang SY, Sroga GE, Vashishth D. Differences in non-enzymatic glycation and collagen cross-links between human cortical and cancellous bone. Osteoporos Int. 2013;24:2441-7.

28. Saito M, Saito M, Marumo KMSKM. Collagen cross-links as a determinant of bone quality: a possible explanation for bone fragility in aging, osteoporosis, and diabetes mellitus. Osteoporos. Int M. 2010;21:195-214. Saito, Department of Orthopaedic Surgery, Jikei University School of Medicine, Minato-ku, Tokyo 105-8461, Japan.

29. Sroga GE, Vashishth D. Effects of bone matrix proteins on fracture and fragility in osteoporosis. Curr. Osteoporos. Rep. 2012;10:141-50.

30. Schwartz A V, A.V. S. Diabetes Mellitus: Does it Affect Bone? Calcif. Tissue Int A.V. Schwartz, Dept. of Epidemiol. and Biostatist., Univ. of California San Francisco, San Francisco, CA, United States, United States; 2003;73:515-9.

31. Lindsey JB, Cipollone F, Abdullah SM, McGuire DK. Receptor for advanced glycation end-products (RAGE) and soluble RAGE (sRAGE): cardiovascular implications. Diab Vasc Dis Res. 2009;6:7-14.
32. Schmidt AM, Yan SD, Yan SF, Stern DM. The biology of the receptor for advanced glycation end products and its ligands. Biochim Biophys Acta. 2000;1498:99-111.

33. Abate M, Schiavone C, Salini V, Andia I. Management of limited joint mobility in diabetic patients. Diabetes, Metab Syndr Obes Targets Ther. 2013:6:197-207.

34. Atienzar P, Abizanda P, Guppy A, Sinclair AJ. Diabetes and frailty: An emerging issue. Part 1: Sarcopaenia and factors affecting lower limb function. Br J Diabetes Vasc Dis. 2012;12:110-6

35. Lebiedz-Odrobina D, Kay J. Rheumatic manifestations of diabetes mellitus, Rheum Dis Clin North Am. 2010;36:681-99.

36. Milaneschi $Y$, Tanaka T, Milaneschi Y, Tanaka T, Ferrucci LYMTTLF. Nutritional determinants of mobility. Curr Opin Clin Nutr Metab Care. 2010;13:625-9. L. Ferrucci, Longitudinal Studies Section, Clinical Research Branch, National Institute on Aging, Baltimore, MD 21225, United States.

37. Semba RD, Nicklett EJ, Ferrucci L. Does accumulation of advanced glycation end products contribute to the aging phenotype? J Gerontol A, Biol Sci Med Sci. 2010;65:963-75

38. Toth C, Martinez J, Zochodne DW. RAGE, diabetes, and the nervous system Curr Mol Med. 2007;7:766-76. C. Toth, University of Calgary, Department of Clinical Neurosciences, Calgary, AB T2N 4N1, Canada.

39. Wrobel JS, Najafi B. Diabetic foot biomechanics and gait dysfunction. J Diabetes Sci Technol. 2010;4:833-45.

40. EBRO. Dutch Cochrane Center. EBRO Assessment tool of Cohort Studies. available at http://dcc.cochrane.org/beoordelingsformulieren-en-anderedownloads

41. Rosnow RL, Rosenthal R. Computing contrasts, effect sizes, and counternulls on other people's published data: General procedures for research consumers. Pyschological Methods, 1996;1:331-40.

42. Cohen J. Statistical Power Analysis for the Behavioural Sciences. 2nd ed Hillsdale: Erlbaum; 1988.

43. Dalal M, Ferrucci L, Sun K, Beck J, Fried LP, Semba RD, et al. Elevated serum advanced glycation end products and poor grip strength in older community-dwelling women. Journals Gerontol - Ser A Biol Sci Med Sci. 2009;64:132-7. R. D. Semba, Baltimore, MD 21205, United States.

44. Momma H, Niu K, Kobayashi Y, Guan L, Sato M, Guo H, et al. Skin advanced glycation end product accumulation and muscle strength among adult men. Eur J Appl Physiol. 2011:111:1545-52.

45. Semba RD, Bandinelli S, Sun K, Guralnik JM, Ferrucci L. Relationship of an advanced glycation end product, plasma carboxymethyl-lysine, with slow walking speed in older adults: the InCHIANTI study. Eur J Appl Physiol. 2010:108:191-5.

46. Sun $K$, Semba RD, Fried LP, Schaumberg DA, Ferrucci L, Varadhan $R$. Elevated serum carboxymethyl-lysine, an advanced glycation end product, predicts severe walking disability in older women: the women's health and aging study I. J Aging Res. 2012;2012:586385.

47. Whitson HE, Arnold AM, Yee LM, Mukamal KJ, Kizer JR, Djousse L, et al. Serum carboxymethyl-lysine, disability, and frailty in older persons: the Cardiovascular Health Study. Journals Gerontol A, Biol Sci Med Sci. 2014:69:710-6.

48. Tanaka K, Kanazawa I, Sugimoto T. Elevated Serum Pentosidine and Decreased Serum IGF-I Levels are Associated with Loss of Muscle Mass in Postmenopausal Women with Type 2 Diabetes Mellitus. Exp. Clin. Endocrinol. Diabetes. I. Kanazawa. Japan: Department of Internal Medicine 1, Shimane University Faculty of Medicine, Izumo; 2015. p. 693-8501.

49. La Maza MPD, Uribarri J, Olivares D, Hirsch S, Leiva L, Barrera G, et al. Weight increase is associated with skeletal muscle immunostaining for advanced glycation end products, receptor for advanced glycation end products, and oxidation injury. Rejuvenation Res. 2008;11:1041-8.

50. Shah KM, Clark BR, McGill JB, Lang CE, Maynard J, Mueller MJ. Relationship between skin intrinsic fluorescence-an indicator of advanced glycation end products-and upper extremity impairments in individuals with diabetes mellitus. Phys Ther. 2015;95:1111-9 9. Department of Physical Therapy, Arcadia University, Clenside, Pennsylvania: American Physical Therapy Association.

51. Haus JM, Carrithers JA, Trappe SW, Haus JM, Carrithers JA, Trappe SW, et al. Collagen, cross-linking, and advanced glycation end products in aging human skeletal muscle. J Appl Physiol. 2007;103:2068-76. T.A. Trappe, Human Performance Laboratory, Ball State Univ.. Muncie, IN 47306 United States.

52. Prehogan A, Cohen $\mathrm{Cl}$. Motor dysfunction in dementias. Geriatrics. 2004:59(53-4):56,59-60. 
53. Meerwaldt R, Graaff R, Oomen PH, Links TP, Jager JJ, Alderson NL, et al. Simple non-invasive assessment of advanced glycation endproduct accumulation. Diabetologia. 2004;47:1324-30.

54. Kilhovd BK, Juutilainen A, Lehto S, Ronnemaa T, Torjesen PA, Birkeland KI, et al. High serum levels of advanced glycation end products predict increased coronary heart disease mortality in nondiabetic women but not in nondiabetic men: a population-based 18-year follow-up study. Arterioscler Thromb Vasc Biol. 2005;25:815-20.

55. Kilhovd BK, Juutilainen A, Lehto S, Ronnemaa T, Torjesen PA, Hanssen KF, et al. Increased serum levels of advanced glycation endproducts predict total, cardiovascular and coronary mortality in women with type 2 diabetes: a population-based 18 year follow-up study. Diabetologia. 2007;50:1409-17.

56. Prasad C, Imrhan V, Marotta F, Juma S, Vijayagopal P. Lifestyle and Advanced Glycation End Products (AGEs) burden: its relevance to healthy aging. Aging Dis. 2014;5:212-7.

57. Couppé C, Svensson R, Grosset J, Kovanen V, Nielsen R, Olsen M, et al. Life-long endurance running is associated with reduced glycation and mechanical stress in connective tissue. Age (Omaha). C. Couppé, Department of Physical Therapy, Musculoskeletal Rehabilitation Research Unit, Bispebjerg Hospital, Copenhagen, Denmark, Netherlands; 2014;36:9665.

Submit your next manuscript to BioMed Central and we will help you at every step:

- We accept pre-submission inquiries

- Our selector tool helps you to find the most relevant journal

- We provide round the clock customer support

- Convenient online submission

- Thorough peer review

- Inclusion in PubMed and all major indexing services

- Maximum visibility for your research

Submit your manuscript at www.biomedcentral.com/submit
Biomed Central 